\title{
ESSAY
}

\section{COMPLEX TAX LEGISLATION IN THE TURBOTAX ERA}

\begin{abstract}
Lawrence Zelenak*
When tax returns were prepared with pencil and paper-in an era now gone forever-Congress did not impose income tax provisions of great computational complexity on large numbers of taxpayers, in the belief that it was unreasonable to require average taxpayers (or their paid preparers) to struggle with computationally complex provisions. As return preparation software gradually replaced the pencil in recent decades, the complexity constraint weakened and eventually disappeared. Congress has responded by imposing unprecedented computational complexity on large numbers of taxpayersprimarily through the expanded scope of the alternative minimum tax and the proliferation of phase outs of credits, deductions, and exclusions. This response would not be problematic, if the only objection to computational complexity were the difficulty of performing the calculations-a difficulty overcome by the widespread adoption of software. Unfortunately, computationally complex provisions generally constitute bad tax policy, even apart from computational concerns. For taxpayers faced with a welter of computationally complex provisions, the income tax is a black box, the inner workings of which are beyond their comprehension. This undermines both the political legitimacy of the tax system and the ability of taxpayers to engage in informed tax planning. In response to the demise of the complexity constraint, argues this Essay, Congress should develop a self-imposed constraint against the enactment (or survival) of computationally complex provisions of widespread applicability.
\end{abstract}

* Pamela B. Gann Professor of Law, Duke Law School. Author email: zelenak@law.duke.edu 


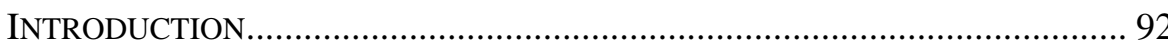

I. RETURN PREPARATION SOFTWARE: A BRIEF HISTORY ............. 94

II. SUBSTANTIVELY ATTRACTIVE COMPUTATIONALLY

COMPLEX PROVISIONS: MORE THAN A THEORETICAL

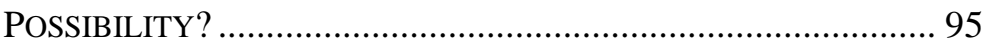

III. THE ROLE OF SOFTWARE IN FACILITATING THE

ENACTMENT OF BAD TAX POLICIES...................................... 98

A. The Alternative Minimum Tax ….................................... 99

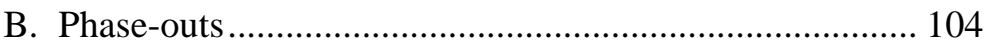

IV. IS THERE A STRUCTURAL SOLUTION?.................................. 116

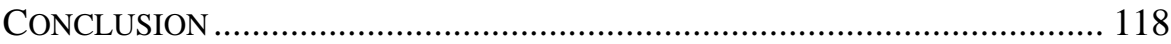

\section{INTRODUCTION}

In the past thirty years, computer software has revolutionized the preparation of federal income tax returns. ${ }^{1}$ When all returns were prepared by hand, Congress was greatly constrained in its ability to impose computationally complex provisions on large numbers of taxpayers. Taxpayers preparing their own returns would have objected vociferously to the computational burden. Taxpayers resorting to paid preparers would have objected to the price demanded by paid preparers to wrestle with complexity. Even return preparation firms might have objected-despite the increased demand for their services-if they could not find enough employees able to perform the required calculations.

With few returns now prepared by hand, however, the computational complexity constraint on the income tax rules applicable to large numbers of taxpayers has virtually disappeared. With only a few Luddites clinging to their pencils, and with computers available to perform calculations of any degree of complexity in milliseconds, the practicalities of return preparation impose virtually no limitations on the computational complexity to which Congress may subject the average taxpayer. To be clear: Software provides only modest assistance in handling complexity in record keeping and data entry, but once the data are entered there are no complexity constraints concerning how the tax rules may instruct the computers to slice and dice the data to produce tax bills. If Congress wants to subject millions of taxpayers to multiple overlapping phase-outs of various deductions and credits, if Congress wants to impose the alternative minimum tax on half the taxpaying population, or if Congress desires tax

1. For the history of the introduction and adoption of return preparation software, see infra notes 2-13 and accompanying text. 
rate schedules featuring hundreds of different marginal tax rates, it can now achieve its goals. In the TurboTax era, mere computational complexity does not rule out any legislative innovation.

Whether this is a boon or a curse is debatable. On the boon side, it may be possible to identify substantively attractive but computationally complex tax reforms, which would have been impractical in the pencil-andpaper era, but which can and should be enacted in the age of TurboTax. On the curse side, however, it may be that computationally complex tax rules are usually bad rules for reasons other than mere computational complexity, that the complexity constraint of bygone days served a valuable function by preventing the enactment of such rules, and that Congress may respond to the elimination of the constraint by enacting a myriad of computationally complex and substantively indefensible provisions. Worse yet, perhaps Congress has already so responded.

Part I of this Essay offers a brief history of how return preparation software routed the humble pencil. Part II considers whether the elimination of the computational complexity constraint might lead to the enactment of substantively desirable tax policies that were previously impractical. It concludes that the theoretical possibility exists, but that it is frustratingly difficult to identify any concrete examples. Part III considers whether the disappearance of the complexity constraint has facilitated the enactment of tax rules that are objectionable apart from their computational complexity. It argues that provisions of major computational complexity and widespread applicability usually constitute bad tax policy even when computers are available to do all the number crunching. Such provisions render the take system opaque to the average taxpayer, making it impossible for taxpayers to evaluate whether their tax liabilities are generated by a fair set of rules, and making it impossible for taxpayers to engage in informed tax planning. It concludes that the elimination of the complexity constraint has led to the enactment of a number of objectionable provisions, and that it will continue to do so unless Congress succeeds in replacing the complexity constraint with self-restraint. Part IV considers mandatory "tax complexity analyses" of current law and of proposed legislation, which Congress has required since 1998. It argues that this structural reform has had little or no effect in constraining complexity, and that there is no reason to expect it to be any more effective in the future. Part IV is a brief conclusion. It contends that what is needed is not structural reform, but a basic change in attitudes-in hearts and mindsamong the members of Congress. This may be too much to hope for-but if it is, then there is no hope. The conclusion urges Congress to adopt, in the place of the complexity constraint, an informal presumption against the enactment (or survival) of computationally complex provisions of 
widespread applicability, on the grounds that such provisions generally constitute bad tax policy even when software is available to handle all the computations.

\section{RETURN PREPARATION SOFTWARE: A BRIEF HISTORY}

The earliest tax return preparation software was developed by a handful of small

companies in the late 1970s and early 1980s. ${ }^{2}$ The early adopters were overwhelmingly paid preparers, rather than taxpayers preparing their own returns. For example, in 1982 Jackson Hewitt-now the nation's second largest tax preparation service, but then just a small business in Virginia - took the radical step of using self-developed software to prepare all its customers' returns. ${ }^{3}$ By 1987, about a quarter of all paid preparer returns were being produced on computers. ${ }^{4}$ Newspaper and magazine stories about the possibility of self-preparers using software did not appear until 1983. ${ }^{5}$ Data do not exist on the extent of software use by selfpreparers in the 1980s, but according to a leading expert on the growth of the use of return preparation software "[i]t is reasonable to infer that very few self-preparers used software" even towards the end of the decade. ${ }^{6}$

The greatest growth in the use of return preparation software occurred from the mid-1980s to the mid-1990s. Only $13 \%$ of all individual returns had been prepared on computers in $1987,{ }^{7}$ but $67 \%$ of all returns for tax year 1997 were computer-prepared. ${ }^{8}$ This included $87 \%$ of paid preparer returns and $45 \%$ of self-prepared returns. ${ }^{9}$ Much of the growth in

2. Don Nunes, Computer Programs Aid Tax Return Preparation, WASH. Post, Feb. 14, 1983, at 23.

3. Daniel B. Grunberg, Case Study: Information Technology at Jackson Hewitt Tax Service, 15 J. OF CONSUMER MARKETING 282, 283 (1998).

4. Eric Toder, Changes in Tax Preparation Methods, 1993-2003, 107 TAX NoTES 759, 759 (2005) (reporting that 13\% of all 1987 returns were prepared on computers, that $48 \%$ of all individual taxpayers used paid preparers, and that "very few" self-preparers used software).

5. Nunes, supra note 2; Ellen Benoit, The Tax Preparation Revolution, FORBES, Jan. 17, 1983, at 69. More stories appeared the following year. David E. Sanger, Software for Doing Your Own Return, N.Y. TiMES, Mar. 4, 1984, at 76; John W. Hazard, Doing Your Taxes by Computer, U.S. News \& World RePORT, Mar. 19, 1984, at 86; William D. Marbach, Now, the Electronic Tax Man, NEwsweEK, Mar. 19, 1984, at 106.

6. Toder, supra note 4, at 759 (Toder's comment refers specifically to 1987).

7. Id. at 759 .

8. Data Release, Taxpayer Usage Study, 1997, StATistics of InCOME BulLetin 131, 131 (Summer 1998).

9. Author's calculations, based on id. at 135 tbl.1. Of all individual returns for 1997, $54 \%$ were prepared by paid preparers, and $46 \%$ by taxpayers themselves. Author's 
software use during this period was attributable to the pencil-to-software transition by industry giant H\&R Block. Block did not use return preparation software at all until $1990,{ }^{10}$ and did not complete the transition to software until $1993 .^{11}$

By tax year 2006 (the most recent year for which data are available), $89 \%$ of all individual returns were prepared on computers. ${ }^{12}$ This included $98 \%$ of paid preparer returns and $71 \%$ of self-prepared returns. $^{13}$ In light of the seemingly inexorable trend, it is very likely that the data for returns for tax year 2008, when they become available, will indicate that fewer than one return in ten is now being prepared using pencil and paper.

\section{SUBSTANTIVELY ATtRACTIVE COMPUTATIONALLY COMPLEX PROVISIONS: MORE THAN A THEORETICAL POSSIBILITY?}

It is not necessarily a bad thing that tax return computational complexity no longer serves as a constraint on federal income tax legislation. Perhaps there are some tax reform proposals lurking in the wings, which in the pre-TurboTax era would have been too computationally complex to enact, but which would have been good tax policy apart from their computational complexity. If so, tax return preparation software has now overcome the complexity problem, and the proposals can and should be enacted. The story of the demise of the Rule of 78s in the wake of the widespread availability of financial calculators provides an analogy. Before the availability of inexpensive financial calculators, the IRS permitted taxpayers to calculate interest by the inaccurate-but-easy-to-apply Rule of 78's. ${ }^{14}$ In 1982 Hewlett-Packard introduced the HP 12C, the world's first

calculations, based on id. at 135 tbl.1.

10. H\&R Block, Inc., 1991 ANNUAL REPORT 10 (reporting that Block "field tested" return preparation software in two company-owned districts and a small number of franchise operations in 1990).

11. H\&R Block, Inc., 1993 AnNuAl Report 2 ("For the first time, our income tax services in the U.S. were fully automated in fiscal 1993, enabling us to provide computerized tax returns to virtually all of our clients.").

12. Internal Revenue Service, Tax Year 2006 Taxpayer Usage Study, Report 16, available at http://www.irs.gov/taxstats/article/0,,id=184856,00.html (last visited Feb. 14, 2010).

13. Author's calculations, based on id. Of all individual returns for 2006, 63\% were prepared by paid preparers and $37 \%$ by taxpayers themselves. Author's calculations, based on id.

14. Rev. Rul. 72-100, 1972-1 C.B. 122, 1972 WL 30448 (permitting the use of the Rule of 78's to calculate interest with respect to installment notes with terms of sixty months or less). 
mass-market handheld financial calculator. ${ }^{15}$ The following year the IRS issued a revenue ruling stating that the Rule of 78's "lacks economic substance because it fails to reflect the true cost of borrowing," and concluding that the Rule could no longer be used to calculate interest for purposes of the federal income tax. ${ }^{16}$ The ruling did not mention the advent of the HP 12C, but it is unlikely that the appearance of the ruling shortly after the appearance of the calculator was a coincidence. Perhaps something similar might now happen in response to the near-ubiquity of tax preparation software; perhaps some superior tax legislative policies requiring complex tax return calculations can now be enacted.

It is easy enough to acknowledge the theoretical possibility that such policies might exist. It is much more difficult to think of concrete examples of such policies. Two possibilities come to mind, but both are far from compelling. The first is the introduction of continuously variable marginal tax rates. When optimal tax analysts investigate the attributes of the tax-and-transfer systems that would maximize various social welfare functions under various conditions, they generally find that the optimal income tax features continuously varying marginal tax rates, so that each dollar of a taxpayer's income would be taxed at a different rate. ${ }^{17}$ Prior to the development and widespread use of return preparation software, implementation of such a tax rate structure would have been impossible, no matter how compelling the theoretical case in its favor. Today, software could handle the computational complexity with ease.

Should Congress respond to the near-ubiquity of return preparation software by enacting continuously varying marginal tax rates? Probably not. Optimal tax analysts generally find that the social welfare improvements from continuously varying rates, in comparison with a limited number of tax brackets—or, indeed, with a single ("flat") rate-are quite modest. ${ }^{18}$ And these modest improvements do not take into account

15. Tim Carvell, The Product Hewlett-Packard Couldn't (and Shouldn't) Kill, FORTUNE, Dec. 9, 1996, at 40.

16. Rev. Rul. 83-84, 1983-1 C.B. 97, 1983 WL 190117. The ruling was accompanied by a narrow exception, permitting the continued use of the Rule of 78's in connection with certain short-term consumer loans. Rev. Proc. 83-40, 1983-1 C.B. 774. 1983 WL 189227. The exception survived for more than a decade, before it was finally "obsoleted". Rev. Proc. 97-37, 1997-2 C.B. 455, 1997 WL 430911.

17. See, e.g., Matti Tuomala, Optimal Income Tax and Redistribution 95-99 (1990) (presenting optimal marginal tax rate curves based on a variety of social welfare functions and factual assumptions; in most simulations the marginal tax rate rises through the bottom ten percent of the wage distribution, but declines thereafter).

18. The seminal work on optimal income tax analysis is James Mirrlees, An Exploration in the Theory of Optimum Income Taxation, 38 REV. ECON. STUD. 175 (1971). As later scholars have noted, Mirrlees made the surprising "discovery . . . that, at least in the cases he considered, the optimal non-linear tax structure was approximately linear!” Joel 
the negative effects of continuously varying rates, in terms of taxpayer confusion and incomprehension, and in terms of frustration of tax planning (which requires knowledge of one's marginal tax rate or rates). Once the negative effects were factored in, the detriments of continuously varying rates would probably outweigh the benefits, even with return preparation software doing all the computational heavy lifting. One prominent optimal tax study, concerning the relative merits of a flat tax and a two-bracket system concluded, "[T]he benefits of allowing two brackets rather than one are very sensitive to the parameterization of the problem and may or may not be sufficient to justify the additional administrative cost." ${ }^{9}$ If the optimal tax benefits of something as simple as a two-bracket system may not be worth the trouble caused by the introduction of the second bracket, it is not likely that the optimal tax benefits of continuously varying rates would be sufficient compensation for the inevitable incomprehension and interference with tax planning. Many taxpayers would not understand either the policy justification for or the mechanical operation of continuously varying rates, and even taxpayers who did understand the rate structure in theory would be unable to determine their effective marginal tax rate(s) for planning purposes.

For another example of a tax policy, the realization of which might be promoted by the spread of return preparation software, consider proposals to eliminate income tax marriage penalties on two-earner couples by allowing spouses to file separate returns (using the section 1(c) rates applicable to single persons, rather than the unfavorable section 1(d) rates currently applicable to married persons filing separate returns) if their combined separate return liabilities are less than their joint return liability. A bill permitting optional separate filing passed the Senate in 1999, but never became law. ${ }^{20}$ In an era of pencil-and-paper tax return preparation, it would have been a serious objection to optional separate filing that it requires a couple to prepare three tentative returns-one joint and two separate-in order to determine whether joint filing or separate filing produces the lower tax liability. With taxpayers in 1999 in the midst of the transition from pencils to software, this objection still had some force. It would, however, have almost no force today. If one believed in 1999 that optional separate filing would be good tax policy, but for the need to prepare three tentative returns, then in 2009 one should whole-heartedly support optional separate filing. Preparing and comparing three tentative returns is no challenge for software.

Slemrod, Shlomo Yitzhaki, Joram Mayshear, \& Michael Lundholm, The Optimal TwoBracket Linear Income Tax, 53 J. PuB. ECON. 269, 270 (1994).

19. Slemrod et al., supra note 18, at 285.

20. Taxpayer Refund Act of 1999, S. 1429, 106th Cong., § 201. 
Unfortunately, the case for optional separate filing is weak, even in 2009. For one thing, optional separate filing not only introduces the computational complexity of tentative returns, it also introduces the noncomputational complexity of allocating income, deduction, and credit items between the spouses for purposes of the separate returns. Software offers no assistance in dealing with complexity of this sort. More fundamentally, there is a powerful argument that optional separate filing would be bad tax policy on the merits, even if it created no complexity of any kind. The objection is that optional separate filing is philosophically incoherent. ${ }^{21}$ The standard policy justification for having joint returns at all-rather than simply requiring all married persons to file separate returns under the same rate structure applicable to unmarried persons-is that married couples function as economic units, so that two married couples with the same combined income should have the same tax liability regardless of the division of the incomes between the spouses in each marriage. But consider two equal-income couples under an optional separate filing regime. In one marriage, all the income is earned by one spouse, while in the other marriage half the income is earned by each spouse. The former couple will file a joint return, while the latter couple will file two separate returns and pay less tax. The purpose of a joint return system is to impose equal tax on equal income couples, but optional separate filing fatally undermines that purpose.

To sum up: In theory, the near-universal use of return preparation software might facilitate the introduction of desirable tax rules previously impeded by computational complexity. It is extremely difficult, however, to identify even one compelling example of such a rule. It is much easier to identify examples of the opposite phenomenon—bad tax policies the introduction of which would have been impeded by computational complexity in the pencil-and-paper era, but which survive and flourish in the age of TurboTax. The next section of this Essay considers this phenomenon.

\section{THE ROLE OF SOFTWARE IN FACILITATING THE ENACTMENT OF BAD TAX POLICIES}

Under current law, the major sources of computational complexity impacting large numbers of taxpayers are the alternative minimum tax (AMT) and the phase-outs of various deductions, exclusions and credits for

21. For a fuller development of the argument against optional separate filing based on philosophical incoherence, see Lawrence Zelenak, Doing Something About Marriage Penalties: A Guide for the Perplexed, 54 TAx L. REV. 1, 17-19 (2000). 
taxpayers with incomes above the various phase out thresholds. As detailed below, the impact of both the AMT and of phase-outs has increased dramatically over the same period that software has supplanted the pencil as the dominant return preparation tool. It would probably be impossible to prove a direct causal connection between the ascendancy of software and the increasing computational complexity of the average tax return. Indeed, a major theme of this Essay is that increasing complexity does not inevitably follow from the spread of software; Congress can and should replace the computational complexity constraint on tax legislation with selfrestraint. Nevertheless, there is good reason to suspect that it is no accident that the increase in tax return complexity has coincided with the triumph of return preparation software. ${ }^{22}$

This section begins by examining the AMT, and then turns to phase-outs. It demonstrates how both the AMT and phase outs have expanded as software usage has increased, and explains why both the expanding reach of the AMT and the proliferation of phase outs are bad policy, even if no one ever again prepares a tax return without computer assistance.

\section{A. The Alternative Minimum Tax}

The minimum tax was introduced in 1969, more than a decade before the first computer-prepared tax return. ${ }^{23}$ The purpose was to ensure that taxpayers with high economic incomes could not avoid substantial tax liabilities by aggressively exploiting exclusions, deductions, and credits. ${ }^{24}$ Since 1978, the minimum tax has taken the form of an "alternative" minimum tax. ${ }^{25}$ Having computed her regular tax liability by applying the regular tax rates to her regular taxable income, the taxpayer must calculate her tentative minimum tax by applying the AMT tax rates to her AMT tax base, which is defined as her alternative minimum taxable income (“AMTI”) in excess of the AMT exemption amount. ${ }^{26}$ The rules defining

22. It is not possible here to disprove alternative explanations for the increase in tax return complexity. Perhaps, for example, Congress has recently become persuaded that the pursuit of an equitable distribution of tax burdens requires an increase in computational complexity, and Congress would have so decided even if tax return software had not been available to handle the computations. Occam's razor, however, strongly favors the explanation suggested in the text-that the widespread availability of return preparation software eliminated the complexity constraint and Congress responded by enacting widely applicable tax laws of unprecedented computational complexity.

23. Tax Reform Act of 1969, Pub. L. No. 91-172, §301, 83 Stat. 487, 580-81.

24. S. Rep. No. 313, 99th Cong., 518-19 (2d Sess. 1986).

25. Revenue Act of 1978, Pub. L. No. 95-600, § 421, 92 Stat. 2763, 2871-72.

26. I.R.C. § 55(b)(1) (2009). 
AMTI disallow a number of tax preferences (exclusions and deductions) that are permitted for purposes of the regular tax. ${ }^{27}$ If the tentative minimum tax exceeds the taxpayer's regular tax liability, she must pay that excess as her AMT liability (in addition, of course, to paying the regular tax). ${ }^{28}$ AMT calculations greatly increase the difficulty of pencil-and-paper tax return preparation, but if the taxpayer (or her paid preparer) uses software the computational difficulties vanish.

In 1970 (the first year in which the minimum tax applied), only 20,000 taxpayers were subject to the minimum tax. ${ }^{29}$ The number of affected taxpayers generally increased in subsequent years-albeit with large year-to-year fluctuations in both directions. ${ }^{30}$ By far the greatest increase in the number of taxpayers subject to the AMT, however, has occurred in the past decade. The number of taxpayers subject to the AMT more than tripled from 1.3 million in 2001 to 4.0 million in $2005 .^{31}$

The primary cause of this increase was the fact that the 2001 and 2003 reductions in the regular income tax ${ }^{32}$ (some of which were phased in over several years) were not accompanied by parallel reductions in the AMT. ${ }^{33}$ As taxpayers' regular tax liabilities declined over the decade and their tentative minimum taxes did not, many taxpayers' tentative minimum taxes exceeded their regular tax liabilities for the first time. In most cases, these were not the truly wealthy taxpayers who were the original targets of the minimum tax. In 2007, 3.6\% of taxpayers with cash incomes in the $\$ 100,000$ to $\$ 200,000$ range were subject to the AMT, as were $47.0 \%$ of taxpayers with cash incomes in the $\$ 200,000$ to $\$ 500,000$ range, and $57.2 \%$ of taxpayers with cash incomes ranging from $\$ 500,000$ to $\$ 1,000,000 .^{34}$ By contrast, only $37.3 \%$ of taxpayers with cash incomes above $\$ 1,000,000$

27. I.R.C. § 55(b)(2) (2009).

28. I.R.C. § 55(a) (2009).

29. Greg Leiserson \& Jeffrey Rohaly, The Individual Alternative Minimum Tax: Historical Data and Projections, Updated June 2008, TAx POLICY CENTER 10, Tbl.2 (June 25, 2008), available at http://www.taxpolicycenter.org/publications/url.cfm?ID=411703 (last visited Feb. 14, 2010).

30. See id. tbl.2.

31. See id. tbl.2. In 20064.0 million taxpayers were again subject to the AMT, and in 2007 (the most recent year for which data are available) the tax applied to 4.1 million taxpayers. Id.

32. Economic Growth and Tax Relief Reconciliation Act of 2001, Pub. L. No. 107-16, 115 Stat. 38 (2001); Jobs and Growth Tax Relief Reconciliation Act of 2003, Pub. L. No. 108-27, 117 Stat. 752 (2003).

33. Gregg A. Esenwein, Congressional Research Service, Report for Congress: The Alternative Minimum Tax for Individuals: Legislative Initiatives and Their Revenue Effects (CRS/RS 22563) (updated May 22, 2007), at 1 (on file with Columbia Journal of Tax Law).

34. Leiserson \& Rohaly, supra note 29 , at 11 tbl.3. 
were subject to the AMT. ${ }^{35}$

The two leading AMT preference items today are not the sort of wealthy, investor tax preference items at which the AMT was originally targeted. In 2006, state and local tax deductions constituted 70.57 percent (by dollar amount) of all AMT preferences, and personal exemptions

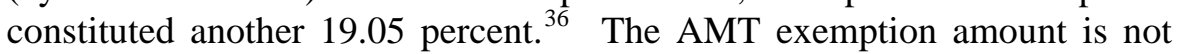
indexed for inflation (unlike the analogous provisions of the regular tax), but Congress has been enacting annual AMT "patches" in lieu of a permanent fix for this problem. ${ }^{37}$ If Congress should ever fail to enact a "patch," the number of taxpayers affected by the AMT would increase tremendously, to more than 30 million. $^{38}$

No one can state with certainty whether Congress would have been willing to subject almost three million more taxpayers (the difference between 1.3 million in 2001 and 4.1 million in 2007) to the AMT in this decade, in a world of pencil-and-paper tax return preparation. It is reasonable to surmise, however, that in that alternate universe, complaints of computational complexity would have been a serious impediment to the exclusion of the AMT from the tax reductions of 2001 and 2003. But with more than four out of five returns for tax year 2001 prepared on computers, ${ }^{39}$ and with the expectation that the dominance of software would only increase over time, Congress had no reason to fear major taxpayer objections to the computational complexity of the expanding AMT.

The question remains: if the computational complexity of the AMT is no longer a problem in the TurboTax era, what is wrong with imposing the AMT on millions-or even tens of millions-of taxpayers? When it urged the repeal of the AMT in its 2005 Report, the President's Advisory Panel on Federal Tax Reform ("Panel”) condemned the AMT solely on the basis of computational complexity: "Eliminating the AMT would free millions of middle-class taxpayers . . . from filing the forms, preparing the worksheets, and making the seemingly endless calculations required to

35. Id. at 11 .

36. Tax Policy Center, AMT Preference Items, 2002, 2004-2006 1, available at http://www.taxpolicycenter.org/taxfacts/displayfact.cfm?Docid=468 (last visited Feb. 14, 2010).

37. See, e.g., American Recovery and Reinvestment Tax Act of 2009, Pub. L. No. 1115, §1012, 123 Stat. 115 (enacting the AMT “patch” for 2009).

38. Leiserson \& Rohaly, supra note 29, at 11 tbl.3 (estimating that 34.8 million taxpayers will be subject to the AMT in 2010 in the absence of a "patch" for that year).

39. According to the Internal Revenue Service, $80.16 \%$ of 2001 returns were prepared on computers. Internal Revenue Service, Tax Year 2001 Taxpayer Usage Study, Report 14, available at http://www.irs.gov/taxstats/article/0,,id=184856,00.html (follow “2002” link under “Archives”) (last visited Feb. 14, 2010). 
determine their AMT liability." 40 Somehow the Panel missed the fact that very few taxpayers (or their paid preparers) actually wrestle with these forms, worksheets, and calculations, because the vast majority of AMT returns are now prepared on computers (and virtually all are likely to be computer-prepared in the near future). If this is the only objection to a burgeoning AMT, then there is really no meaningful objection.

Tax historian Joseph Thorndike shares the view of this Essay that, as a political matter, computationally complex tax provisions of wide applicability can survive and flourish in the TurboTax era, and he ruefully predicts that the AMT-which he excoriates as "a bad tax, a blight on the nation's revenue structure" - will not "cause enough pain to ensure its own demise." ${ }^{41}$ Like the Panel, however, Thorndike does not explain what is so objectionable about the AMT, when millions of computers stand ready to do all the number-crunching. Despite his lack of explanation, Thorndike is right - the AMT is a bad tax, even with those millions of computers at the ready.

The fundamental problem is that the AMT turns the tax system into a black box for those taxpayers to whom it applies. TurboTax or a paid preparer will tell the taxpayer his overall tax liability, but the taxpayer may not focus on the portion of that liability attributable to the AMT. Even if the taxpayer happens to notice the amount of his AMT, he will almost certainly not understand the derivation of that figure. To that taxpayer, the tax system is a black box, producing a tax liability through some incomprehensible process. There are two serious objections to a black-box tax system.

The first objection is grounded in civics. As Charles McLure has noted, a black-box tax system is "hardly a recipe for good governance in a democracy." 42 If taxpayers do not have at least a rough idea of the process through which their tax liabilities are determined, they can have no way of evaluating the fairness of the tax system, as applied either to themselves or to others. ${ }^{43}$ Taxation without comprehension is as inimical to democracy as

40. President's Advisory Panel on Federal Tax Reform, Simple, Fair, and Pro-Growth: Proposals to Fix America's Tax System, 211 TAx Notes Today 14 (Nov. 2, 2005).

41. Joseph J. Thorndike, The Great Noncrisis of the AMT, 107 TAX NOTES 245 (2005).

42. Charles E. McLure, Jr., Economics and Tax Reform: 1986 and Now, 113 TAX Notes 362 (2006).

43. The workings of the AMT are not completely opaque to a highly observant TurboTax user. TurboTax features a small box near the top of the computer screen, which keeps a running score of the taxpayer's underpayment or overpayment on the assumption that the taxpayer has already made all data entries. It can be a disturbing experience for a TurboTax user subject to the AMT to enter a five-figure state and local tax deduction and see the number in the small box change only a little or not at all. 
taxation without representation. ${ }^{44}$

The second objection relates to the ability of taxpayers to engage in well-informed basic tax planning, and to respond appropriately to the many incentives Congress has embedded in the tax laws. If a taxpayer is unable to determine whether he is subject to the AMT until after the end of the tax year (that is, until after the return has been prepared), he will be unable to determine whether his marginal tax rate is that of the regular tax or that of the AMT. As a result, he will be unable to determine (for example) his after-tax cost of charitable giving, or his after-tax return from earning extra income. Worse yet, in the case of AMT preference items, the taxpayer will be unable to determine whether the favorable regular tax treatment of those items is available to him. A taxpayer may take out a second mortgage, relying on the deductibility of interest on home equity indebtedness under the regular $\operatorname{tax},{ }^{45}$ only to be blindsided by the nondeductibility of such interest under the AMT. ${ }^{46}$ Or a taxpayer may buy a house in a highproperty-tax jurisdiction, relying on the income tax deductibility of the property tax, ${ }^{47}$ only to lose the deduction under the AMT. ${ }^{48}$ Or consider a taxpayer who bought a hybrid car before 2009, expecting to receive a widely-advertised tax credit, only to discover too late that the credit was not allowed for purposes of the AMT and that the AMT applied to the taxpayer. ${ }^{49}$

If AMT taxpayers are induced to engage in behavior which is taxfavored under the regular tax-either not realizing they are subject to the AMT, or not realizing that the tax preference is not available under the AMT - the result is manifestly unfair. The other possibility is just as troubling - that taxpayers not subject to the AMT may fail to respond to incentives in the regular income tax, based on an awareness that the incentives do not apply under the AMT and a fear that they may be subject to the AMT. As Austan Goolsbee has commented, a black box tax system

44. See Lawrence Zelenak, Justice Holmes, Ralph Kramden, and the Civic Virtues of a Return Filing Requirement, 61 TAX L. REV. 53, 71-72 (2007) (arguing that the income tax return filing requirement can have the "civic virtue" of making taxpayers conscious of the distribution of the costs of government, but that that benefit is lost if taxpayers perceive the income tax "as a black box, producing income tax liabilities through the use of incomprehensible rules that taxpayers have no reason to assume are fair").

45. I.R.C. § 163(h)(3)(C) (2009).

46. I.R.C. $\S 56$ (b)(1)(C)(i) (2009).

47. I.R.C. § 164(a)(2) (2009).

48. I.R.C. § 56(b)(1)(A)(ii) (2009).

49. See Lawrence Zelenak, Of Prius Buyers, Blue States, Consumer Energy Credits, and the Alternative Minimum Tax, 109 TAX Notes 657 (Oct. 31, 2005). As recently amended, $\S 30 \mathrm{~B}(\mathrm{~g})(2)$ now provides that the hybrid vehicle credit may be claimed against the AMT as well as the regular tax. 
wreaks havoc with tax incentives:

If people do not understand the incentives embodied in the system, they will not respond to them. On the one hand, this makes the system efficient and nondistortionary . . . . On the other hand, the ability to influence behavior was exactly the policymakers' point in creating the complex tax system to begin with. In the long run that purpose would be lost. ${ }^{50}$

Perhaps the costs of a black-box AMT of widespread applicability would be worth bearing, if the AMT served a sufficiently important purpose that could not be served in some simpler fashion. But applying the AMT to millions of less-than-wealthy taxpayers, largely by reason of their living in high-tax states or having children, does nothing to serve the original purpose of the AMT (that is, to ensure that wealthy taxpayers could not avoid substantial income tax liabilities by aggressively taking advantage of various tax preferences). ${ }^{51}$ And neither Congress nor commentators have suggested any new policy rationale for the tax as it currently exists-other than mere revenue raising, which could be pursued more simply and more rationally in any number of other ways.

\section{B. Phase-outs}

The use of phase-outs in the income tax dates back at least to the 1954 Code. $^{52}$ Section 214 of the 1954 Code allowed a deduction for up to

50. Austan Goolsbee, The TurboTax Revolution: Can Technology Solve Tax Complexity?, in The Crisis in TAX Administration 124, 138 (Henry J. Aaron \& Joel Slemrod eds., 2004).

51. See supra note 24 and accompanying text.

52. Provisions which allow deductions only to the extent expenditures exceed some specified percentage of adjusted gross income (AGI), and provisions which phase-in benefits as income increases, both resemble phase-outs in terms of computational complexity, taxpayer confusion, and the production of effective marginal tax rates different from statutory marginal tax rates under I.R.C. $\S 1$. Because of these similarities, analysts frequently discuss percentage-of-AGI floors and phase-ins along with phase-outs. See, e.g., Staff of the Joint Comm. on Taxation, 105th Cong., Present Law and Analysis RElating to Individual EfFective Marginal TAX RATES JCS-3-98 (1998). Floors and phase-ins are not considered here, however, because - in sharp contrast with phase-outsthey have not proliferated as the use of return preparation software has expanded in recent decades. The three significant percentage-of-AGI floors in the individual income tax are the 7.5\% floor applicable to medical expenses (Internal Revenue Act of 1954, Pub. L. No. 83591, §213(a), 68A Stat. 3, 69 (imposing a 3\%-of-AGI floor; under current I.R.C. §213(a) the floor is $7.5 \%$ )), the $10 \%$ floor on personal casualty losses (Tax Equity and Fiscal 
$\$ 600$ of dependent care expenses, but reduced the otherwise allowable deduction (in the case of taxpayers filing a joint return) by the amount by which adjusted gross income (AGI) exceeded $\$ 4,500 .^{53}$ A second phaseout was added to the income tax with the introduction of the earned income tax credit (EITC) in $1975 .{ }^{54}$ A qualifying taxpayer with exactly $\$ 4,000$ of earned income was entitled to a $\$ 400$ credit. The credit was reduced, however, by 10 percent of the amount by which the taxpayer's income exceeded $\$ 4,000$ (with the phase-out thus completed at $\$ 8,000$ ).

Phase-outs remained rare in the income tax until the 1980s. Legislation enacted in 1983 phased out half of the exclusion of Social Security benefits from gross income, pursuant to a complex formula. ${ }^{55}$ The Tax Reform Act of 1986 added a provision designed to phase out the benefit of personal exemptions and the benefit of the 15 percent tax bracket (as compared to the 28 percent tax bracket). ${ }^{56}$ The provision imposed a special tax equal to five percent of the excess of the taxpayer's taxable income over a specified phase-out threshold (based on filing status), with the maximum special tax liability limited to the tax reduction attributable to personal exemptions and the 15 percent bracket. ${ }^{57}$ For taxpayers in the

Responsibility Act of 1982, Pub. L. No. 97-248, §203(a), 96 Stat. 324, 422 (now codified at I.R.C. §165(h)(2))), and the $2 \%$ floor applicable to miscellaneous itemized deductions (Tax Reform Act of 1986, Pub. L. No. 99-514, §132, 100 Stat. 2085, 2113-16 (now codified at I.R.C. §67)). The two significant phase-ins are the phase-in of the earned income tax credit (Tax Reduction Act of 1975, Pub. L. No. 94-12, §204, 89 Stat. 26, 30-32 (now codified at I.R.C. §32(b))), and the phase-in of the refundability of the child tax credit (Economic Growth and Tax Reconciliation Act of 2001, Pub. L. No. 107-16, §201(c), 115 Stat. 38, 46 (now codified at I.R.C. §24(d))).

As explained later in this Essay (see supra notes 87-92 and accompanying text), in recent years Congress has used phase-outs for two purposes: to impose hidden marginal tax rate increases on all or nearly all taxpayers in particular income ranges, and to target new tax benefits to lower- and middle-income taxpayers. Because neither percentage-of-AGI floors nor phase-ins are well suited to either of these purposes, the removal of the complexity constraint has not prompted a flurry of floor and phase-in legislation.

53. Internal Revenue Act of 1954, Pub. L. No. 83-591, §214, 68A Stat. 3, 70-71.

54. Tax Reduction Act of 1975, Pub. L. No. 94-12, §204, 89 Stat. 26, 30-32 (now codified at I.R.C. §32). The 1975 version of the EITC was a temporary provision, but Congress made the credit permanent in 1978. Revenue Act of 1978, Pub. L. No. 95-600, $\S 103,92$ Stat. 2761, 2771.

55. The formula reduced the exclusion by the amount by which the sum of the taxpayer's modified adjusted gross income and half of the taxpayer's Social Security benefits exceeded a "base amount" (\$25,000 for unmarried taxpayers, and \$32,000 for taxpayers filing joint returns). Social Security Amendments of 1983, Pub. L. No. 98-21, $\S 121,97$ Stat. 65, 80-82 (now codified at I.R.C. §86(c)).

56. Tax Reform Act of 1986, Pub. L. No. 99-514, §101(a), 100 Stat. 2085, 2097-98 (formerly codified at I.R.C. §1(g)).

57. The 1986 Act also introduced an analogous phase-out of the AMT exemption amount. Tax Reform Act of 1986, Pub. L. No. 99-514, §701(a), 100 Stat. 2085, 2320-22 (now codified at I.R.C. §55(d)(3)). 
phase-out range the official marginal tax rate was 28 percent, but the effective marginal tax rate-considering both the official rate and the phase-out-was 33 percent. Once the phase-out was completed (that is, once the benefits of the personal exemptions and the 15 percent bracket had been fully taxed away), the effective marginal tax rate dropped to 28 percent. As is typically the case with phase-outs, the result was an effective marginal tax rate "bubble", with taxpayers in the phase-out range subject to higher effective marginal tax rates than taxpayers at both lower and higher income levels. The 1986 Act also introduced an income-based phase-out of the ability to make deductible individual retirement account (IRA) contributions, applicable to active participants in tax-favored employmentbased retirement plans. ${ }^{58}$

Phase-outs became a significant feature of the income tax in the 1980s, but the most dramatic growth in phase-outs occurred in the following decade. In 1990 Congress repealed the five percent phase-out tax of the 1986 Act, ${ }^{59}$ only to replace it with two new phase-outs. One of the new phase-outs reduced otherwise allowable itemized deductions by the lesser of (1) three percent of the excess of AGI over $\$ 100,000$, or (2) 80 percent of otherwise allowable itemized deductions. ${ }^{60}$ The other phase-out reduced the dollar amount of otherwise allowable personal exemptions by two percentage points for each $\$ 2,500$ by which the taxpayer's AGI exceeded a specified threshold amount (based on filing status). ${ }^{61}$ In 1993 Congress revisited the exclusion of Social Security benefits, providing for the phase-out of 85 percent of the exclusion for some taxpayers. ${ }^{62}$ The banner year for phase-outs was 1997, in which Congress introduced the child tax credit, ${ }^{63}$ the Hope scholarship and lifetime learning credits, ${ }^{64}$ the deduction for interest on student loans, ${ }^{65}$ Roth IRAs, ${ }^{66}$ and educational

58. Tax Reform Act of 1986, Pub. L. No. 99-514, §1101(a), 100 Stat. 2085, 2411-14 (now codified at I.R.C. §219(g)).

59. Omnibus Budget Reconciliation Act of 1990, Pub. L. No. 101-508, §11101(b), 104 Stat. 1388, 1388-404.

60. Omnibus Budget Reconciliation Act of 1990, Pub. L. No. 101-508, § 11103(a), 104 Stat. 1388, 1388-406 (now codified at I.R.C. § 68).

61. Omnibus Budget Reconciliation Act of 1990, Pub. L. No. 101-508, § 11104(a), 104 Stat. 1388, 1388-407 (now codified at I.R.C. § 151(d)(3)).

62. Omnibus Budget Reconciliation Act of 1993, Pub. L. No. 103-66, § 13215, 107 Stat. 312, 475-76 (now codified at I.R.C. § 86(a)(2)).

63. Taxpayer Relief Act of 1997, Pub. L. No. 105-34, § 101(a), 111 Stat. 788, 796-98 (now codified at I.R.C. § 24).

64. Taxpayer Relief Act of 1997, Pub. L. No. 105-34, § 201(a), 111 Stat. 788, 799-803 (now codified at I.R.C. § 25A).

65. Taxpayer Relief Act of 1997, Pub. L. No. 105-34, § 202(a), 111 Stat. 788, 806-08 (now codified at I.R.C. § 221).

66. Taxpayer Relief Act of 1997, Pub. L. No. 105-34, § 302(a), 111 Stat. 788, 825-28 
savings accounts ${ }^{67}$-each with its own phase-out provision, reducing or eliminating the ability of higher-income taxpayers to claim the tax benefit.

In 1998, in response to the proliferation of phase-outs, the Staff of the Joint Committee on Taxation published a lengthy report describing and evaluating income tax provisions "that can result in a taxpayer's effective marginal tax rate deviating from the statutory marginal tax rate.” ${ }^{\text {„8 }}$ The Staff identified eighteen such phase-out provisions. ${ }^{69}$ Some of the provisions were highly specialized and affected few taxpayers, but others were of widespread applicability. The Staff reported the number of taxpayers whose marginal tax rates were affected by the various phase-out provisions: 11.7 million by the phase-out of the EITC, 5.0 million by the partial phase-out of the exclusion of Social Security benefits, 4.5 million by the limitation on itemized deductions, 1.6 million by the partial phase-out of the dependent care credit, 1.5 million by the phase-out of eligibility to make deductible IRA contributions, 1.4 million by the phase-out of personal exemptions, and 1.2 million by the phase-out of the Hope scholarship and lifetime learning credits (combined). ${ }^{70}$ Because of its focus on effective marginal tax rates, the Staff provided no estimates of the numbers of taxpayers with incomes above the various phase-out ranges, whose tax liabilities were increased by the phase-outs but whose effective marginal tax rates were not.

The pace of phase-out legislation slowed after 1997, and in 2001 Congress even made a show of repealing two prominent phase-outs-the limitation on itemized deductions and the phase-out of personal exemptions. $^{71}$ However, in the spirit of St. Augustine praying for chastity- "Give me chastity and self-control, but not just yet" Congress delayed the repeals for many years. The repeals had no effect until 2006. In 2006 and 2007 they reduced the otherwise applicable phaseout amounts by one-third, and in 2008 and 2009 by two-thirds. The repeal is fully effective in 2010-but only in 2010, because the repeals (in

(now codified at I.R.C. § 408A).

67. Taxpayer Relief Act of 1997, Pub. L. No. 105-34, § 213(a), 111 Stat. 788, 813-16 (now codified at I.R.C. § 24).

68. STAFF OF THE JOINT COMM. ON TAXATION, supra note 52.

69. Id. at 4-9 chart 1. Altogether, the Staff identified twenty-two provisions that could cause effective marginal tax rates to differ from statutory rates. The non-phase out provisions were a small number of percentage-of-AGI floors on deductions and phase-ins of tax benefits. Floors and phase-ins are discussed earlier. See supra note 52.

70. StAFF OF THE JOINT Comm. ON TAXATION, supra note 52, at 4-7 chart 1.

71. Economic Growth and Tax Relief Reconciliation Act of 2001, Pub. L. No. 107-16, $\S 102,115$ Stat. 38, 44 (relating to the phase-out of personal exemptions), § 103, 151 Stat. 38 , 44-45 (relating to the limitation on itemized deductions).

72. St. Augustine, Confessions 173 (Garry Wills trans., 2006). 
common with all the 2001 tax reductions) are scheduled to "sunset" at the end of this year. ${ }^{73}$ Congress continues to enact new phase-outs from time to time, although not at the pace of the 1990s. For example, the first-time homebuyer credit enacted in 2008 is subject to an income-based phaseout, ${ }^{74}$ as was the one-time "recovery rebate" created by 2008 legislation. ${ }^{75}$ In addition to enacting new phase-outs, Congress has designed some phaseout provisions so that their impact increases over time without the need for additional legislation. These are the phase-out provisions with AGI thresholds that are not indexed for inflation; the most important example is the phase-out of the child tax credit, the phase-out thresholds of which have remain unchanged (\$110,000 for taxpayers filing joint returns, and $\$ 75,000$ for unmarried taxpayers) since enactment. ${ }^{76}$ In 1998 only 0.6 million taxpayers had effective marginal tax rates affected by the phase-out of the child tax credit. ${ }^{77}$ Comparable data are not available for recent years, but with the thresholds badly eroded by inflation it is probable that several times that many taxpayers are affected today. ${ }^{78}$

Data on the numbers of taxpayers affected by the various phaseouts is much harder to come by than data on the number of taxpayers affected by the AMT. Although the 1998 report of the Staff of the Joint Committee on Taxation included a comprehensive analysis of the numbers of taxpayers with effective marginal tax rates affected by the various provisions as of $1998,{ }^{79}$ nothing comparable is available for more recent years. It is clear, however, that in the aggregate, phase-outs impact a tremendous number of taxpayers. According to the National Taxpayer Advocate (NTA), more than 60 million returns of individuals for tax year 2004 were "affected by one or more phaseouts," as were more than 70 million returns for tax year 2006. ${ }^{80}$ The total number of individual returns

73. Economic Growth and Tax Relief Reconciliation Act of 2001, Pub. L. No. 107-16, $\S 901,115$ Stat. 38, 150.

74. Housing and Economic Recovery Act of 2008, Pub. L. No. 110-289, § 3011(a), 2888-91 (codified at I.R.C. § 36).

75. Economic Stimulus Act of 2008, Pub. L. No. 110-185, § 101(a), 122 Stat. 613, 613-15 (codified at I.R.C. § 6428).

76. I.R.C. § 24(b) (2009).

77. STAFF OF THE JOINT COMM. ON TAXATION, supra note 52, at 6 chart 1.

78. If the thresholds had been adjusted for inflation since 1998 , the $\$ 75,000$ threshold would now be approximately $\$ 98,000$, and the $\$ 110,000$ threshold would now be approximately $\$ 144,000$. Bureau of Labor Statistics Inflation Calculator, available at http://data.bls.gov/cgi-bin/cpicalc.pl (last visited Feb. 14, 2010).

79. StafF OF THE Joint COMm. On TAXATiOn, supra note 52, at 4-9 chart 1.

80. National Taxpayer Advocate, 2006 Annual Report to Congress 470 (2006); National Taxpayer Advocate, 2008 Annual Report to Congress 410 (2008). There is an important ambiguity in the NTA's statistics. It is unclear whether the numbers reflect only those taxpayers with effective marginal tax rates affected by phase-outs (as in the case of 
for tax year 2006 was 138.4 million, ${ }^{81}$ so according to the NTA most returns were affected by phase-outs. Because there is considerable overlap in the income ranges over which the various phase-outs operate, ${ }^{82}$ many taxpayers have effective marginal tax rates influenced by more than one phase-out.

From the history recounted above, it is apparent that the complexity constraint did not prevent the enactment of some phase-outs during the pencil-and-paper era of tax return preparation. The 1954 enactment of the phase-out of the dependent care credit and the 1975 enactment of the phaseout of the EITC predate even the earliest use of return preparation software, and the phase-outs of the 1986 Act were introduced when only about one return in eight was prepared on a computer. ${ }^{83}$ It is impossible to say whether taxpayers and their paid preparers would have tolerated the profusion of widely applicable phase-outs in the current income tax-and especially the simultaneous applicability of several phase-outs to the same taxpayer-if return preparation software had never been developed. It seems unlikely, however, that it is merely a coincidence that by the time of the phase-out-strewn Taxpayer Relief Act of 1997, 67 percent of all

StAFF OF THE JoInt Comm. ON TAXATION, supra note 52, at 4-9 chart 1), or whether the numbers also include taxpayers with incomes above the phase-out ranges of the various credits. If the NTA's numbers reflect only those taxpayers with phase-out-affected marginal tax rates, then the total number of taxpayers affected by phase-outs must be even higher than the numbers reported by the NTA.

81. I.R.S. Individual Income Tax Returns 2006, Publication 1304 (Rev. 07-2008), at 2 tbl.A.

82. Consider, for example, the following 2009 phase-out ranges applicable to taxpayers filing joint returns. For 2009 (or any other year, given the absence of an inflation adjustment), the phase-down range for the dependent care credit was $\$ 15,000$ to $\$ 43,001$. I.R.C. $\S 21(a)(2)$ (2009). For the phase-out of the child tax credit (which also lacks an inflation adjustment), the phase-out range was $\$ 110,000$ to 129,001 for taxpayers with one qualifying child, $\$ 110,000$ to $\$ 149,001$ for taxpayers with two qualifying children, $\$ 110,000$ to $\$ 169,001$ for taxpayers with three qualifying children, and so on. I.R.C. § 24(b) (2009). For the EITC, the 2009 phase-out range for a couple with two qualifying children was $\$ 21,420$ to $\$ 45,295$. REV. Proc. 2009-21, § 4.06, 2009 IRB Lexis 147. The 2009 phase-out range for the Hope scholarship credit was $\$ 160,000$ to $\$ 180,000$. I.R.C. $\S$ 25A(i)(4) (2009). The 2009 phase-out threshold for the limitation on itemized deductions was \$166,800. Rev. Proc. 2008-66, § 3.11, 2008-2 C.B. 1107. (Because of the unusual design of this phase-out, there is no generally applicable higher end of the phase-out range.) The 2009 phase-out range for personal exemptions was \$250,000 to \$372,700. REv. Proc. 2008-66, § 3.19(2), 2008-2 C.B. 1107. The 2009 phase-out range for eligibility to make deductible IRA contributions (for active participants in employment-based retirement plans) was $\$ 89,000$ to $\$ 109,000$. Notice 2008-102, 2008-2 C.B. 1106 . The 2009 phase-out range for the deductibility of interest on student loans was $\$ 120,000$ to $\$ 150,000$. REV. Proc. 2008-66, § 3.23, 2008-2 C.B. 1107. For eligibility to make contributions to Roth IRAs, the 2009 phase-out range was $\$ 166,000$ to $\$ 188,000$. Notice 2008-102, 2008-2 C.B. 1106.

83. Toder, supra note 4 , at 759 . 
[Vol. 1:91

individual returns were prepared on computers. ${ }^{84}$

The growing use of return preparation software does not lead inexorably to the proliferation of phase-outs. Congress might choose to resist the phase-out impulse despite the removal of the complexity constraint. The 2001 semi-repeal of the limitation on itemized deductions and of the phase-out of personal exemptions-fully effective only for the single year of $2010^{85}$ - provides evidence of at least a limited legislative ability to resist. In deciding whether to resist, Congress should ask with respect to phase-outs the same sort of questions it should ask with respect to the AMT. In a world in which tax return computational complexity is no longer an issue, is it nevertheless important to repeal many, most, or all phase-outs? What, if anything, is objectionable about phase-outs if computers are able and willing to do all the number crunching? The answers are basically the same as the answers to the parallel questions concerning the AMT. Like the AMT, phase-outs turn the income tax into a black box, imperiling both the political legitimacy of the income tax and the ability of taxpayers to engage in informed tax planning. If phase-outs make it difficult or impossible for taxpayers to understand the process by which their tax liabilities are determined (especially when phase-out confusion interacts with AMT confusion), taxpayers can have no confidence that their own tax liabilities and the tax liabilities of their fellow citizens are being determined by fair rules. And if taxpayers do not understand the phase-out rules-both the rules in the abstract, and how the rules apply in their particular circumstances-their tax planning ability is severely compromised.

The tax planning problem can take two different forms. A standard critique of phase-outs is that they impose hidden marginal tax rate increases, thereby leading taxpayers to overestimate their after-tax returns to additional labor effort. ${ }^{86}$ Spouses in the phase-out range of the child tax credit, for example, may know their official marginal tax rate (under I.R.C. $\S 1$ ) is 25 percent, and so may assume that their after-federal-income-tax income from earning an additional $\$ 1,000$ will be $\$ 750$ - not realizing that the phase-out of the child tax credit increases their effective marginal tax rate to 30 percent and decreases the after-tax benefit of the additional $\$ 1,000$ to $\$ 700$. This critique takes as a given the existence of the creditgenerating activity (in this case, having a "qualifying child” for purposes of

84. Data Release, supra note 8, at 131.

85. See supra notes 71-73 and accompanying text.

86. See, e.g., STAFF OF THE JOINT COMM. ON TAXATION, supra note 52, at 99; RiCHARD SCHMALBECK \& LAWRENCE ZELENAK, FEDERAL InCOME TAXATION 39 (2d ed. 2007); Robert J. Peroni, Reform in the Use of Phase-Outs and Floors in the Individual Income Tax System, 91 TAX NOTES 1415, 1431 (2001). 
the child tax credit), and treats the production of the additional income as the marginal activity affected by the phase-out.

Although the fact is much less commonly noted, the planning effects of a phase-out are quite different-but no less objectionable-if the amount of the taxpayer's pre-tax income is taken as the given and the existence (or dollar amount) of the credit-generating activity is treated as the tax-influenced decision. Suppose, for example, spouses are trying to determine whether they can afford to send their child to a private college. They rely on the existence of the Hope scholarship credit in their analysis, only to discover - too late to be used in their decision-making process - that they are entitled to a diminished credit, or no credit at all, because of the phase-out. In this case, the unfairness of the phase-out provision relates not to a disguised marginal tax rate increase, but to an illusory tax incentive.

If phase-outs further sufficiently important tax policy goals, they might constitute good tax policy on balance, despite their unfortunate black box effects. In that case, the removal of the complexity constraint by the growth in computer-assisted tax return preparation would be a commendable development. In fact, however, the policy arguments in favor of phase-outs are weak.

In analyzing the policy merits of phase-outs, the first step is to distinguish between two different legislative motivations for the enactment of different phase-out provisions. One group of phase-outs is characterized by a cynical legislative purpose-to impose hidden tax rate increases on large numbers of taxpayers with incomes at or above the phase-out ranges, without encountering the political opposition that would arise in response to a straightforward increase in tax rates. The second group consists of phaseouts that are motivated by sincere (albeit generally misguided) legislative concerns about limiting the cost to the fisc of tax expenditure programs and about targeting those programs to income groups where the need is greatest.

Only two phase-outs belong unambiguously in the first group-the limitation on itemized deductions and the phase-out of personal exemptions. There are two defining features of phase-outs in this category; both features must exist for a phase-out clearly to fit the category. First, a phase-out of this sort applies to tax benefits that are so widely available (but for the phase-out) that the effect of the phase-out closely approximates an increase in the tax rates applicable to all taxpayers with incomes in or above the phase-out range. This is true of both the limitation on itemized deductions $^{87}$ and the phase-out of personal exemptions. ${ }^{88}$ It is not true of

87. The vast majority of taxpayers with incomes at or above the phase-out range itemize deductions, and even more would do so but for the limitation on itemized deductions. See generally Reed Shuldiner \& David Shakow, Lessons from the Limitation on 
most other phase-out provisions. For example, in any given year most taxpayers do not incur child care expenses, incur higher education expenses, buy a home for the first time, pay interest on student loans, or contribute to IRAs. The second defining feature of a cynically-inspired phase-out is that the existence of the tax benefit subject to the phase-out predated the enactment of the phase-out-thus demonstrating that Congress did not originally consider the phase-out an intrinsic part of the design of the tax benefit. Itemized deductions existed for decades before the enactment of the limitation on itemized deductions, and personal exemptions were in the income tax long before the introduction of their phase-out. By contrast, most other phase-outs-including those of the child tax credit, the Hope scholarship and lifetime learning credits, the EITC, the first-time homebuyer's credit, the deduction for interest on student loans, and eligibility to contribute to Roth IRAs - were part of the original enactments of the tax benefits to which they relate. ${ }^{89}$

There is nothing to be said in defense of type-one (cynical) phaseout provisions. They produce complexity and confusion, and they are motivated by a congressional intent to deceive. If one takes seriously the 2001 semi-repeal of these provisions ${ }^{90}$ - delayed, phased in, and temporary-it seems that not even Congress itself approves of these phaseouts. According to the Staff of the Joint Committee on Taxation, the 2001 Congress believed that both the limitation on itemized deductions and the phase-out of personal exemptions were "unnecessarily complex way[s] to impose taxes and that the 'hidden' way in which [both provisions] raise[] marginal tax rates undermines respect for the tax laws." ${ }^{91}$ The bottom line on type-one phase-outs is clear. They are an unmitigated tax policy disaster, with no place in a well-designed tax system. As a political matter, however, they may be able to survive in an environment in which software has eliminated the computational complexity constraint.

The legislative motivation for type-two phase-outs is very different. When Congress enacted the original EITC in 1975, the inclusion of a phase-out was undoubtedly driven by a sincere desire to limit the EITC's wage subsidy to those families most in need of assistance, and to control the

Itemized Deductions, 93 TAX Notes 673 (2001) (detailed empirical analysis of taxpayers subject to the limitation on itemized deductions).

88. Any taxpayer subject to the exemption would be able to claim at least one personal exemption-for herself or himself-but for the phase-out.

89. For the histories of these and other phase-out provisions, see supra notes 52-78 and accompanying text.

90. See supra notes 71-73 and accompanying text.

91. StAFF OF THE Joint Comm. On TAXATION, General Explanation of Tax Legislation Enacted in the 107 ${ }^{\text {th }}$ Cong., 13-14 (JCS-1-03) (2003). 
overall cost of the EITC program. ${ }^{92}$ Similar concerns about targeting and controlling program costs explain the inclusion of phase-outs in the original enactments of many other tax benefits, including the child tax credit, the Hope scholarship and lifetime learning credits, the student loan interest deduction, the first-time homebuyer's credit, and the recent recovery rebates.

Recognizing the much more commendable motivation underlying type-two phase-outs, commentators who call for immediate repeal of typeone phase-outs are generally more accepting of type-two phase-outs. Robert J. Peroni, for example, flatly states that the limitation on itemized deductions and the phase-out of personal exemptions "should both be repealed as should all other phase-out provisions that are designed to increase the progressivity of the tax system." ${ }^{93}$ In sharp contrast, he concludes that type-two phase-outs have a legitimate place in the income tax: "The most appropriate use of phase-out ... provisions is as a means of targeting the tax provision in question to reach a group of taxpayers in a specified income range." 94

In fact, however, the substantive case against type-two phase-outs closely resembles the substantive case against type-one phase-outs. Despite legislative good intentions, a type-two phase-out produces the same deleterious black box impacts as a cynically motivated type-one phase-out. But does not a type-two phase-out, unlike a type-one phase-out, serve legitimate targeting and cost control purposes? It does not, at least on the assumption that Congress has the option to modify the official tax rate schedule (under I.R.C. § 1 ) in lieu of phasing out a newly-enacted tax benefit.

To illustrate, suppose the adoption credit of current law ${ }^{95}$ did not exist, and that Congress is contemplating the creation of an adoption credit. Congress is willing to accept only some specified level of revenue cost with respect to the credit. Instead of controlling the cost by enacting the credit with a phase-out, Congress could enact the credit without a phase-out and simultaneously increase marginal tax rates under I.R.C. § 1 (presumably focusing on the marginal rates applicable to higher-income taxpayers) so that the net revenue cost of the credit and the increase in the official tax rate schedule equals the revenue cost Congress would have been willing to

92. The committee reports emphasized the congressional desire to target the credit at low-income wage earners. S. REP. No. 94-36, at 33 (1975), reprinted in 1975-1 C.B. 590, 595; H.R. REP. No. 94-19, at 10, reprinted in 1975-1 C.B. 569, 573-74.

93. Peroni, supra note 86, at 1433.

94. Id. at 1434 .

95. I.R.C. § 23 (2009). The credit is phased out for higher-income taxpayers. I.R.C. $\S$ 23(b)(2) (2009). 
accept in the case of a phased-out credit. This approach avoids the black box problems inherent in phase-outs, ${ }^{96}$ and does so at no greater net revenue cost than the alternative phased-out version of the credit. Under this approach the adoption credit would be available to high income taxpayers, but it is not apparent why that should be objectionable as long as the accompanying adjustments to the official tax rate schedule impose an appropriate tax burden on high income taxpayers as a group (taking into account that some high income taxpayers will benefit from the new credit). If one takes the reasonable position that, ceteris paribus, a high income taxpayer with adoption expenses should have a modestly lower tax liability than a high income taxpayer without such expenses, the availability of the credit to high income taxpayers is not merely unobjectionable; it is desirable. In short, a credit without a phase-out, but accompanied by an appropriate adjustment in the official tax rate schedule, has several virtues and no vices. It avoids all the evils of phase-outs, limits the net revenue loss to the desired amount, does not produce vertical inequity, and distinguishes appropriately at all income levels between taxpayers with and without adoption expenses. ${ }^{97}$ A phase out would be necessary only if, for some strange reason, it was considered appropriate to distinguish between taxpayers with and without adoption expenses at moderate income levels but not appropriate to distinguish between taxpayers with and without adoption expenses at high income levels. Replace adoption expenses with any other category of expenditures currently eligible for a phased-out deduction or credit, and the above analysis indicates that phase-outs of those other deductions and credits are also not needed to control costs or target benefits.

There are, however, two qualifications to the above analysis. First, the analysis assumes Congress is able to revise the official tax rate schedule as readily as it can enact a phase-out. If rate schedule adjustments are politically constrained while phase-out enactments are not, it is possible that the enactment of a phased-out tax benefit may constitute better policy

96. Assuming the amended tax rate schedule of I.R.C. $\S 1$ follows the standard approach of marginal tax rates increasing with income, this approach also avoids the effective marginal tax rate "bubbles" typically caused by phase-outs.

97. Daniel Shaviro has made this point particularly clearly and forcefully. Phase-outs, he explains, "reflect[] a fundamental misunderstanding-widely shared in the academic literature - of basic design principles. ... [P]haseouts raise questions of overall tax and transfer allocations between households-not of program cost or benefit targeting. Eliminating the phaseout on a revenue-neutral basis would simply mean that some taxpayers' marginal tax rates would drop while others' would increase, permitting implementation of a rate structure that might make more sense overall.” Daniel Shaviro, The Minimum Wage, the Earned Income Tax Credit, and Optimal Subsidy Policy, 64 U. CHI. L. REV. 405, 408-09 (1997). 
than the only politically viable alternatives (that is, not enacting the tax benefit in any form, or enacting the tax benefit without either a phase-out or an adjustment to the official tax rate schedule).

Second, in the case of the phase-out of a provision of wide applicability, such as the EITC, it is conceivable that the effective marginal tax rates produced by the combination of the official tax rate schedule and the phase-out might happen to be appropriate on the merits. Although Congress has never shown any interest in enacting an official tax rate structure featuring a marginal tax rate "bubble" akin to that produced by the combination of the official rate structure and the EITC phase-out-with taxpayers in the phase-out range subject to higher effective marginal tax rates than taxpayers above the phase-out range-optimal tax analysis may provide some support for that sort of effective marginal tax rate structure. Simulations designed to determine the marginal tax rate structure that maximizes a chosen social welfare function ${ }^{98}$ commonly produce rising marginal tax rates at low income levels and declining marginal tax rates at moderate and high income levels. ${ }^{99}$ Of course, it would be the sheerest accident if the effective marginal tax rates produced by a conceptual error (that is, the belief that the EITC must be phased out to target benefits or control costs) happened to be close to the optimal rate structure produced by a completely different analysis.

The bottom line on type-two phase-outs is that, although the congressional motivations for their enactment are benign, on the merits they are generally just as objectionable as the cynically-motivated type-one phase outs. To the extent that computational complexity served as an impediment to the enactment of type-two phase-outs in the era of penciland-paper tax return preparation, the complexity constraint had a favorable tax policy impact. With the elimination of that constraint in the age of TurboTax, some replacement for the constraint must be found to control (or, better yet, to reverse) the proliferation of type-two phase-outs.

98. The social welfare function may be utilitarian (with the well-being of the lessadvantaged members of society given no special weight), or a Rawlsian-style maximin (aimed at maximizing the well-being of the least-advantaged members of society), or anything in between. Lawrence Zelenak \& Kemper Moreland, Can the Graduated Income Tax Survive Optimal Tax Analysis?, 53 TAx L. REV. 51, 52-53 (1999).

99. See, e.g., Louis Kaplow, The Theory of TAXation AND Public Economics 15758 (Princeton University Press 2008); TuOMALA, supra note 17, at 95-99; Daniel N. Shaviro, Welfare, Cash Grants, and Marginal Rates, 59 SMU L. REV. 835, 850 (2006). The intuition behind these results is that high marginal rates at lower income levels raise tax revenue available for social welfare-enhancing redistribution from higher income taxpayers for whom those rates are not marginal, and that the efficiency cost of high marginal rates at low income levels is modest because those rates are inframarginal for most of the taxpayers to whom they apply. Zelenak \& Moreland, supra note 98, at 54-55. 
Developing a satisfactory replacement for the complexity constraint may be even more difficult in this context than in the contexts of the AMT and type-one phase-outs. In the cases of the AMT and type-one phase-outs, Congress is well aware that the provisions are bad policy, and all that is needed to replace the complexity constraint is the development of a legislative backbone. Even that may be easier said than done, but it is a less daunting task than in the case of type-two phase-outs. Congress must first be persuaded that type-two phase-outs constitute bad tax policy, before it can be expected to develop the spine necessary to reject them.

\section{IS THERE A STRUCTURAL SOLUTION?}

It would be nice, at this point in the Essay, to propose a structural reform in the tax legislative process as a replacement for the complexity constraint formerly imposed by the burden of tax return calculations. The proposal might call for mandatory complexity analyses of proposed tax legislation, for the purpose of heightening legislative awareness of complexity concerns and encouraging Congress to look with skepticism upon proposals with high complexity costs. As it happens, however, Congress enacted this structural reform more than a decade ago, and it appears to have done little or no good. Section 4022(a) of the Internal Revenue Service Restructuring and Reform Act of 1998 requires the IRS Commissioner to furnish Congress annually with "an analysis of the sources of complexity in the administration of the Federal tax laws," including recommendations for reducing complexity. ${ }^{100}$ Section 4022(b) of the 1998 Act requires the Joint Committee on Taxation to provide Congress with a "tax complexity analysis" of proposed tax legislation reported by the House Ways and Means Committee, the Senate Finance Committee, or a conference committee, if the proposed legislation includes any provision "which has widespread applicability to individuals or small businesses."101

It will not surprise anyone familiar with the explosive growth of tax expenditures in the years following the institutionalization of tax expenditure budget analysis ${ }^{102}$ that the structural reforms of 1998 have done little or nothing to bring tax complexity under control. The IRS issued its

100. Internal Revenue Service Restructuring and Reform Act of 1998, Pub. L. No. 105206, § 4022(a), 112 Stat. 685, 785.

101. Id. at 785-86.

102. For a history and critical analysis of the tax expenditure budget concept, see STAFF of the Joint Comm. on TAXATION, A Reconsideration of TAx Expenditure AnAlysis (Comm. Print 2008). For the current tax expenditure budget, see STAFF OF THE JoInT Comm. on Taxation, Estimates of Federal TAX Expenditures for Fiscal Years 2009-2013 (Comm. Print 2010). 
first section 4022(a) report in 2000, highlighting the AMT as one of just three sources of complexity discussed in the report. ${ }^{103}$ A year later, Congress responded by enacting massive reductions in the regular income tax without corresponding reductions in the AMT, thereby greatly increasing the number of taxpayers who would be subject to the AMT in later years. ${ }^{104}$ The Joint Committee on Taxation did its job under section 4022(b) with respect to the 2001 legislation. It alerted Congress that by 2010 an estimated "18 million additional individual income tax returns . . . would be affected by the alternative minimum tax" as a result of the proposed 2001 regular tax reductions, ${ }^{105}$ but this did not dissuade Congress from enacting the proposed regular tax reductions. Congress seemed to be mocking the very complexity analyses it had mandated only three years earlier.

The story is not quite so grimly amusing in the case of phase-outs. As noted earlier, ${ }^{106}$ the banner year for the enactment of phase-outs was 1997—a fact that might suggest that the tax complexity analyses required by the 1998 legislation restrained the growth of phase-outs in later years. This seems unlikely, however. For this interpretation to be persuasive, there would have to be some explanation as to why Section 4022 was effective in restraining the growth of phase-outs even as it was dramatically ineffective in restraining the growth of the AMT. No such explanation comes to mind. Moreover, as recounted earlier, Congress has continued to enact new phase-outs in recent years (albeit not at the record-setting pace of 2007), ${ }^{107}$ and has shown little interest in simplifying the law by repealing existing phase-outs. ${ }^{108}$

The problem is that the structural reforms of 1998 cannot force Congress to be serious about resisting tax complexity. This is illustrated by the fact that Congress does not even take the trouble to ensure that it receives the input called for by the 1998 legislation. The IRS Commissioner has never filed another complexity report after the "first annual” report of 2000, and there is no indication in the public record that

103. Internal Revenue Service, Annual Report from the Commissioner of the Internal Revenue Service on Tax Law Complexity, 128-40 TAX NotES TODAY (2000). The other sources of complexity discussed in the report were estimated taxes and filing status determinations.

104. For a description and discussion of the effect of the 2001 legislation on the growth of the AMT, see supra notes 32-35 and accompanying text.

105. H.R. ReP. No. 107-84, at 329 (2001) (Conf. Rep.).

106. See supra notes 63-67 and accompanying text.

107. See supra notes 74-75 and accompanying text.

108. As noted earlier (see supra notes 71-73 and accompanying text), the phase-outs of $\S \S 68$ and 151(d)(3) are scheduled to be eliminated only for the single year of 2010. 
anyone in Congress has complained. ${ }^{109}$ The Joint Committee on Taxation does provide complexity analyses of proposed legislation from time to time, but it is quite willing to declare-in dubious circumstances--that a proposed provision lacks "widespread applicability" and thus is not subject to the complexity analysis requirement. The Joint Committee decided, for example, that a proposed first-time homebuyers' credit (with a phase-out provision) was not subject to complexity analysis because it would not be widely applicable. ${ }^{110}$

In short, the structural reform approach has already been tried, and has failed. The structural reform cannot serve as an adequate replacement for the now-vanished computational complexity constraint, because Congress can-and does-simply ignore the information provided to it by the reform (in those cases in which it even receives the required information). What is needed is not a structural reform, but a changing of Congressional hearts and minds. I hope that is not a counsel of despair.

\section{CONCLUSION}

In the era of pencil-and-paper tax return preparation, Congress refrained from imposing provisions of great computational complexity on large numbers of taxpayers, out of concern that it was unreasonable to require average taxpayers (or their paid preparers) to wrestle with computationally complex provisions. As return preparation software gradually replaced the pencil, the complexity constraint weakened and eventually disappeared. Congress has responded by imposing unprecedented computational complexity on large numbers of taxpayers. This would not be problematic, if the only objection to computational complexity were the difficulty of performing the required calculations without software. Unfortunately, computationally complex provisions generally constitute bad tax policy for reasons other than computational

109. The IRS National Taxpayer Advocate (NTA) regularly discusses tax complexity in her annual reports to Congress. See, e.g., National Taxpayer Advocate, 2008 Annual Report, supra note 80, at 3-14. There is no indication, however, that this is intended as a substitute for the Commissioner's annual complexity reports. The NTA is distinct from the Commissioner, complexity is just one of many issues addressed by NTA reports, and NTA reports are not pursuant to the same legislative mandate as the Commissioner's complexity reports. I.R.C. $\S 7803(\mathrm{c})(2)(\mathrm{B})$ (2009) (requiring the NTA to report annually to Congress, and including a list of topics to be addressed by the annual reports).

110. See, e.g., H.R. REP. No. 110-606, at 72 (2008) (Conf. Rep.) (indicating that the Joint Committee on Taxation declined to provide a tax complexity analysis of a bill containing a number of tax provisions, including a first-time homebuyer's credit with a phase-out, on the grounds that the bill contained no provisions of "widespread applicability”). 
difficulties. Such provisions turn the income tax into a black box, the inner workings of which are incomprehensible to the average taxpayer, thereby undermining both the democratic legitimacy of the tax system and the ability of taxpayers to engage in informed tax planning.

Structural reform - the mandating of "tax complexity analyses" of existing law and proposed legislation-has been tried and has (predictably) failed. In response to the demise of the complexity constraint, Congress must develop a self-imposed constraint, an informal presumption against the enactment (or survival) of computationally complex provisions of widespread applicability. Its goal should be a set of income tax rules under which anyone armed with basic arithmetical skills and a calculator, and with no exotic items of income, deduction, or credit, could easily prepare his or her own tax return with pencil and paper. This should be the goal not because taxpayers will or should return to pencil-and-paper return preparation, but because adhering to this standard ensures tax system transparency, which is crucial for both the political legitimacy of the tax system and for tax planning. It is far from clear that Congress, freed of the complexity constraint in the TurboTax era, can summon the political will to resist the lure of tax complexity. In that possibility, however, lies the only hope for a computationally simpler income tax. 